\title{
Perbandingan Kinerja Jaringan Saraf Tiruan Model Backpropagation dan General Regression Neural Network Untuk Mengidentifikasi Jenis Daging Sapi
}

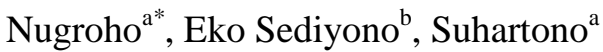 \\ ${ }^{a}$ Magister Sistem Informasi, Universitas Diponegoro, Semarang \\ ${ }^{\mathrm{b}}$ Fakultas Teknologi Informasi, Universitas Kristen Satya Wacana, Salatiga
}

\begin{abstract}
The research on image identification has been conducted to identify the type of beef. The research is aimed to compare the performance of artificial neural network of backpropagation and general regression neural network model in identifying the type of meat. Image management is processed by counting R, G and B value in every meat image, and normalization process is then carried out by obtaining $\mathrm{R}, \mathrm{G}$, and $\mathrm{B}$ index value which is then converted from RGB model to HSI model to obtain the value of hue, saturation and intensity. The resulting value of image processing will be used as input parameter of training and validation programs. The performance of GRNN model is more accurate than the backpropagation with accuracy ratio by $51 \%$.
\end{abstract}

Keyword: Identification; Backpropagation; GRNN

\section{Pendahululuan}

Daging sapi merupakan salah satu sumber protein hewani yang paling disukai oleh masyarakat Indonesia, kebutuhan daging di Indonesia selama lima tahun terakhir terus meningkat. Meningkatnya permintaan tersebut memberikan celah kepada kelompok tertentu untuk memanfaatkan situasi guna meraup keuntungan yang lebih besar. Salah satunya adalah dengan cara menjual jenis daging sapi gelongongan, yaitu sapi yang diberi minum secara paksa sebelum disembelih. Hal ini mengakibatkan bertambahnya kadar air dalam daging, sehingga daging sapi gelonggongan menjadi lebih berat bila dibanding dengan daging sapi segar yang normal.

Kelebihan kadar air dalam daging dapat mengakibatkan penurunan kualitas daging dan mempersingkat waktu simpannya. Penurunan kualitas daging diindikasikan melalui perubahan warna, rasa, aroma bahkan pembusukan. Daging merupakan sumber protein yang mudah dan sering mengalami kerusakan oleh mikroba kerusakan ini disebabkan oleh adanya kontaminasi mikroba pada permukaan daging tersebut pada saat proses karsas dan sebesar $99 \%$ oleh kontaminan bakteri (Raharjo, 2010).

Pengolahan citra memiliki kemampuan yang lebih peka karena dilengkapi dengan sensor elektro-optika yang bisa dipastikan akan lebih tepat dan objektif jika dibanding dengan cara visual manusia yang bersifat subjektif dan sangat dipengaruhi oleh kondisi psikis pengamatnya (Somantri dkk, 2009 a,b).

Teknik pengolahan citra bisa memberikan informasi yang baik jika digabungkan dengan sistem pengambilan keputusan yang bisa memberikan akurasi yang tinggi. Penggunaan jaringan saraf tiruan dapat memberikan hasil optimal, karena memiliki kelebihan dalam menyelesaikan persoalan yang tidak dapat diselesaikan secara analisis (Kusumadewi, 2008).

- $\quad$ Alamat email : nugroho12@yahoo.com*

\section{Teori}

\subsection{Pengolahan Citra}

Citra merupakan istilah lain dari Gambar, yang merupakan informasi berbentuk visual. pada bidang dua dimensi, maka sebuah citra merupakan dimensi spasial atau bidang yang berisi informasi warna yang tidak bergantung waktu. Ditinjau dari sudut pandang matematis, citra merupakan fungsi menerus atas intensitas cahaya pada bidang dua dimensi. Sumber cahaya menerangi objek, objek memantulkan kembali sebagian berkas cahaya tersebut. Pantulan cahaya ini ditangkap oleh alat optik sehingga bayangan objek yang disebut citra tersebut terekam.

Pengambilan citra bisa dilakukan oleh kamera atau alat-alat lain yang bisa digunakan untuk mentransfer Gambar misalnya scanner dan kamera digital. Proses transformasi dari bentuk tiga dimensi ke bentuk dua dimensi untuk menghasilkan citra akan dipengaruhi oleh bermacam-macam faktor yang mengakibatkan penampilan citra suatu benda tidak sama persis dengan bentuk fisik nyatanya. Faktor-faktor tersebut merupakan efek degradasi atau penurunan kualitas yang dapat berupa rentang kontras benda yang terlalu sempit atau terlalu lebar, distorsi, kekaburan (blur), kekaburan akibat objek citra yang bergerak (motion blur), gangguan yang disebabkan oleh interferensi peralatan pembuat citra, baik itu berupa tranducer, peralatan elektronik ataupun peralatan optik karena pengolahan citra digital dilakukan dengan komputer digital maka citra yang akan diolah terlebih dahulu ditransformasikan ke dalam bentuk besaranbesaran diskrit.

Pengolahan warna menggunakan model warna RGB sangat mudah dan sederhana, karena informasi warna dalam komputer sudah dikemas dalam model warna yang sama. Hal yang perlu dilakukan adalah bagaimana kita melakukan pembacaan nilai-nilai $R, G$ dan $B$ pada suatu piksel, salah satu cara yang mudah untuk menghitung nilai 
warna dan menafsirkan hasilnya dalam model warna RGB adalah dengan melakukan normalisasi terhadap tiga komponen warna tersebut. Normalisasi penting dilakukan terutama bila sejumlah citra di ambil dengan kondisi penerangan yang berbeda. Hasil perhitungan tiap komponen warna pokok yang telah dinormalisasi akan menghilangkan pengaruh penerangan, sehingga nilai untuk setiap komponen dapat dibandingkan satu dengan lainya walaupun berasal dari citra dengan kondisi penerangan yang berbeda, dengan catatan perbedaan tersebut tidak terlalu ekstrim (Ahmad, 2005).

$$
\begin{aligned}
R & =\frac{R}{R+G+B} \ldots \ldots \ldots \ldots \ldots \text { (1) } \\
G & =\frac{G}{R+G+B} \ldots \ldots \ldots \ldots \ldots \text { (2) } \\
B & =\frac{B}{R+G+B} \ldots \ldots \ldots \ldots \ldots \text { (3) }
\end{aligned}
$$

Sedangkan untuk mendapatkan besaran nilai model warna HSI korversi model warna RGB ke HSI ini melibatkan parameter, sebagai data masukan (sinyal merah, sinyal hijau dan biru untuk setiap piksel) dan tiga parameterlainya (nilai hue, nilai saturation dan intensity) sebagai keluaran. Transformasi dari model warna RGB ke model warna HSI digunakan untuk mengkonversi citra warna kedalam bentuk yang lebih sesuai untuk pengolahan citra.

$$
\begin{aligned}
& I=\frac{R+G+B}{3} \ldots \ldots \ldots \ldots \ldots \ldots \text { (4) } \\
& \operatorname{Cos} H=\frac{2 R-G-B}{2 \sqrt{(R-G)^{2}+(R-B)(G-B)}} \ldots \ldots \ldots \text { (5) } \\
& S=1-\frac{3}{R+G+B} \min (R, G, B) \cdots(6)
\end{aligned}
$$

\subsection{Jaringan Saraf Tiruan}

Jaringan saraf tiruan adalah sistem pemroses informasi yang memiliki karakteristik mirip dengan jaringan saraf biologi. Jaringan saraf tiruan dibentuk sebagai generalisasi model matematika dari jaringan saraf biologi.

Arsitektur jaringan dan algoritma pelatihan sangat menentukan model-model jaringan saraf tiruan. Arsitektur tersebut gunanya untuk menjelaskan arah perjalanan sinyal atau data di dalam jaringan. Algoritma pelatihan backpropagation adalah sebagai :

1. Inisialisasi
a. Normalisasi data input $\mathrm{x}_{\mathrm{i}}$ dan data target $\mathrm{t}_{\mathrm{k}}$ dalam range $(0,1)$
b. Seluruh pembobot $\left(\mathrm{w}_{\mathrm{ij}}\right.$ dan $\left.\mathrm{v}_{\mathrm{jk}}\right)$ awal diberi nilai random antara $-1,1$
c. Inisialisasi aktivasi thresholding unit, $\mathrm{x}_{0}=1$ dan $\mathrm{h}_{0}=1$

2. Aktivasi unit-unit dari input layer ke hidden layer dengan fungsi :

$$
h_{j}=\frac{1}{1+e^{-\sum w_{i j} x_{i}}}
$$

dimana: $\mathrm{w}_{\mathrm{ij}}=$ pembobot $\mathrm{w}$ yang menghubungkan node unit kei pada input layer dengan noda ke-j pada hidden layer

3. Aktivasi unit-unit dari hidden layer ke output layer dengan fungsi:

$$
y_{k}=\frac{1}{1+e^{-\sigma \sum v_{j k} h_{j}}}
$$

dimana:

$\sigma=$ konstanta logistik (logistic contant)

$\mathrm{v}_{\mathrm{jk}}=$ pembobot $\mathrm{v}$ yang menghubungkan node unit ke-j pada hidden layer dengan noda ke-k pada output layer

4. Menghitung error dari unit-unit pada output layer $\left(\delta_{\mathrm{k}}\right)$ dan menyesuaikannya dengan bobot $\mathrm{v}_{\mathrm{jk}}$

$\delta_{k}=\left(1-y_{k}\right)\left(t_{k}-y_{k}\right)$

dimana:

$\mathrm{t}_{\mathrm{k}} \quad=$ target output pada noda ke- $\mathrm{k}$

$v_{j k}=v_{j k}$ old $+\left(\beta \delta_{k} h_{j}\right)$

dimana :

$\beta=$ konstanta laju pembelajaran

vjk old = pembobot vjk sebelumnya

5. Menghitung error dari unit-unit pada hidden layer $\left(\tau_{\mathrm{j}}\right)$ dan menyesuaikannya dengan bobot $\mathrm{w}_{\mathrm{ij}}$

$$
\begin{gathered}
\tau_{j}=h_{j}\left(1-h_{j}\right) \sum k \delta_{k} v_{j k} \\
w_{i j}=w_{i j} \text { old }+\beta \tau_{j} x_{i} \ldots
\end{gathered}
$$

6. Training set (learning) dihentikan jika $\mathrm{y}_{\mathrm{k}}$ mendekati $\mathrm{t}_{\mathrm{k}}$. Proses pembelajaran juga dapat dihentikan berdasarkan error. Salah satu persamaan untuk nilai error adalah dengan menggunakan Root Mean Square Error (RMSE).

$$
\begin{aligned}
& R M S E=\sqrt{\sum_{i=1}^{n} \frac{\left(p_{i}-a_{i}\right)^{2}}{n}} \ldots \ldots \ldots \ldots . . . . . . \\
& \operatorname{Error}(\%)=\frac{\sum_{i=1}^{n} \frac{p_{i}-a_{i}}{a_{i}}}{n} \times 100 \%
\end{aligned}
$$

Keterangan:

$\mathrm{p}_{\mathrm{i}} \quad=$ nilai dugaan output ulangan ke-i

$\mathrm{a}_{\mathrm{i}} \quad$ = nilai aktual output ulangan ke-i

$\mathrm{n} \quad=$ jumlah contoh data

7. Pengulangan (iterasi)

Keseluruhan proses ini dilakukan pada setiap contoh dari setiap iterasi sampai sistem mencapai keadaaan optimum. Iterasi mencakup pemberian contoh pasangan input dan output, perhitungan nilai aktivasi dan perubahan nilai pembobot, sedangkan algoritma belajar menjelaskan bagaimana bobot koneksi harus diubah agar pasangan masukan-keluaran yang diinginkan dapat tercapai. Dalam setiap perubahan harga bobot koneksi dapat dilakukan 
dengan berbagai cara, tergantung pada jenis algoritma pelatihan yang digunakan. Dengan mengatur besarnya nilai bobot ini diharapkan bahwa kinerja jaringan dalam mempelajari berbagai macam pola yang dinyatakan oleh setiap pasangan masukan-keluaran akan meningkat.

\section{Metode}

\subsection{Bahan}

Bahan yang digunakan dalam penelitian adalah daging sapi segar, daging sapi segar yang dibekukan, daging sapi segar yang didinginkan, daging sapi segar dikeringkan, daging sapi segar direndam, daging sapi gelonggongan, daging sapi busuk, daging busuk yang dibekukan, daging sapi busuk yang didinginkan dan daging sapi busuk dikeringkan.

Tabel 1. Bahan penelitian

\begin{tabular}{|c|c|}
\hline Uji & Definisi \\
\hline $\begin{array}{l}\text { Daging Sapi } \\
\text { Segar }\end{array}$ & $\begin{array}{l}\text { olah dan } \mathrm{t} \\
\text { un. }\end{array}$ \\
\hline $\begin{array}{l}\text { Daging Sapi } \\
\text { Segar } \\
\text { Didinginkan }\end{array}$ & $\begin{array}{l}\text { Daging yang mengalami proses } \\
\text { pendidingan setelah penyembelihan } \\
\text { sehingga temparatur daging antara } 0^{\circ} \mathrm{C} \\
\text { dan } 4^{\circ} \mathrm{C} \text {. }\end{array}$ \\
\hline $\begin{array}{l}\text { Daging Sapi } \\
\text { Segar } \\
\text { Dibekukan }\end{array}$ & $\begin{array}{l}\text { Daging sapi yang sudah mengalami } \\
\text { proses pembekuan dengan temparatur } \\
\text { minimum }-18^{\circ} \mathrm{C} \text {. }\end{array}$ \\
\hline $\begin{array}{l}\text { Daging Sapi } \\
\text { Segar } \\
\text { Direndam }\end{array}$ & $\begin{array}{l}\text { Daging yang mengalami proses } \\
\text { perendaman setelah penyembelihan. }\end{array}$ \\
\hline $\begin{array}{l}\text { Daging Sapi } \\
\text { Segar } \\
\text { Dikeringkan }\end{array}$ & $\begin{array}{l}\text { Daging yang mengalami proses } \\
\text { penjemuran selama } 2 \text { hari } \\
\text { penyembelihan. }\end{array}$ \\
\hline $\begin{array}{l}\text { Daging Sapi } \\
\text { Gelonggongan }\end{array}$ & $\begin{array}{l}\text { Daging yang didapat dari sapi yang } \\
\text { mengalami proses minum yang yang } \\
\text { dilakukan secara paksa can berlebihan } \\
\text { sebelum disembelih. }\end{array}$ \\
\hline $\begin{array}{l}\text { Daging Sapi } \\
\text { Busuk } \\
\text { Daging Sapi } \\
\text { Busuk } \\
\text { Didinginkan }\end{array}$ & $\begin{array}{l}\text { Daging yang mengalami proses } \\
\text { pembusukan setelah penyembelihan. } \\
\text { Daging busuk yang mengalami proses } \\
\text { pendinginan pada suhu } 0^{\circ} \mathrm{C} \text { sampai } \\
\text { dengan } 4^{\circ} \mathrm{C} \text {. }\end{array}$ \\
\hline $\begin{array}{l}\text { Daging Sapi } \\
\text { Busuk } \\
\text { Dibekukan }\end{array}$ & $\begin{array}{l}\text { Daging sapi busuk yang sudah } \\
\text { mengalami proses pembekuan dengan } \\
\text { temparatur minimum }-18^{\circ} \mathrm{C} \text {. }\end{array}$ \\
\hline $\begin{array}{l}\text { Daging Sapi } \\
\text { Busuk } \\
\text { Dikeringkan }\end{array}$ & $\begin{array}{l}\text { Daging yang mengalami proses } \\
\text { penjemuran selama } 2 \text { hari setelah } \\
\text { proses pembusukan. }\end{array}$ \\
\hline
\end{tabular}

Daging sapi yang digunakan sebagai bahan pelatihan dan bahan uji pada penelitian ini disesuaikan dengan kebutuhan, yakni terdiri dari sepuluh jenis daging sapi, beberapa diantaranya sesuai dengan ketentuan Standar Nasional Indonesia (SNI) Nomor 3932:2008 tentang mutu dan karkas daging sapi. Namun terdapat juga daging sapi yang dijadikan objek penelitian tidak memenuhi ketentuan Standar Nasional Indonesia (SNI) Nomor 3932:2008. Bahan dari kesepuluh jenis daging sapi yang digunakan untuk pelatihan dan validasi tidak sama.

\subsection{Alat}

Peralatan yang dibutuhkan untuk melakukan penelitian tentang identifikasi citra untuk mengidentifikasi jenis daging sapi adalah:

Tabel 2. Alat penelitian

\begin{tabular}{ll}
\hline Nama & Keterangan \\
\hline Light Box & $\begin{array}{l}\text { Kotak pengambilan citra dengan } \\
\text { ukuran Panjang 20cm dan lebar } 20 \mathrm{~cm}\end{array}$ \\
Lampu PL & Lampu PL 15 watt 2 buah. \\
Kamera & Samsung PL100 dengan resolusi 12,2 \\
Digital & Mega Pixel \\
& Acer 4710 dengan prosesor T2450 2.00 \\
Laptop & Ghz \\
\hline
\end{tabular}

\subsection{Pengambilan Citra}

Proses pengambilan citra dilakukan dengan menggunakan kamera digital, objek penelitian diletakkan di dalam light box untuk mendapatkan kualitas citra yang maksimal dengan kondisi pencahayaan yang sama antara objek penelitian satu dengan lainya.

\subsection{Pengolahan Citra}

Pengolahan citra dimulai dengan proses cropping image, yaitu suatu proses pemotongan Gambar untuk menghilangkan bagian-bagian Gambar yang tidak diinginkan, hal ini dilakukan untuk mendapatkan citra yang sesuai dengan kebutuhan. Setelah proses cropping proses selanjutnya adalah proses penghitungan nilai-nilai parameter input antara lain $\mathrm{R}, \mathrm{G}, \mathrm{B}$, color value, indeks $\mathrm{R}$, indeks $\mathrm{G}$, indeks $\mathrm{B}$, hue (corak), saturation (kejenuhan) dan intensity.

\subsection{Arsitektur Jaringan Saraf Tiruan}

Arsitektur jaringan saraf tiruan model backpropagation yang dibangun terdiri dari tiga lapisan (layer), yaitu input layer, hidden layer, dan output layer. Sebagai masukan pada input layer adalah data parameter R, G, B, RGB color value, indeks $\mathrm{R}$, indeks $\mathrm{G}$, indeks $\mathrm{B}$, hue (corak), saturation (kejenuhan) dan intensity.

Sedangkan arsitekrur GRNN terdiri dari empat lapisan unit pemroses, dimana tiap lapisan unit pemroses mempunyai fungsi komputasi khusus saat regresi nonlinier dibentuk. Lapisan pertama terdiri dari neuron-neuron input yang berfungsi untuk mengambil informasi. Neuronneuron input lalu meneruskan data menuju lapisan kedua yang dinamakan neuron pola. Sebuah neuron-neuron pola berfungsi mengkombinasikan dan memproses data secara sistematik dengan suatu fungsi aktivasi.

\subsection{Pelatihan}

Tujuan dari pelatihan adalah untuk mendapatkan nilai bobot antar lapisan yang digunakan pada program validasi. Masukan data pelatihan berupa nilai parameter R, G, B, color value, indeks $\mathrm{R}$, indeks $\mathrm{G}$, indeks $\mathrm{B}$, hue, saturation dan intensity. yang didapatkan dari hasil pengolahan citra pada data pelatihan. 


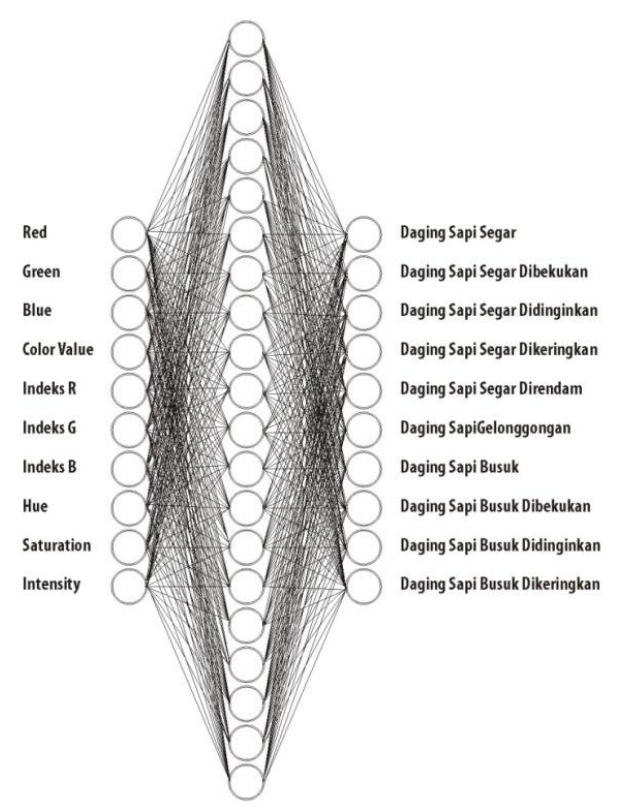

Gambar 1. Arsitektur Backpropagation

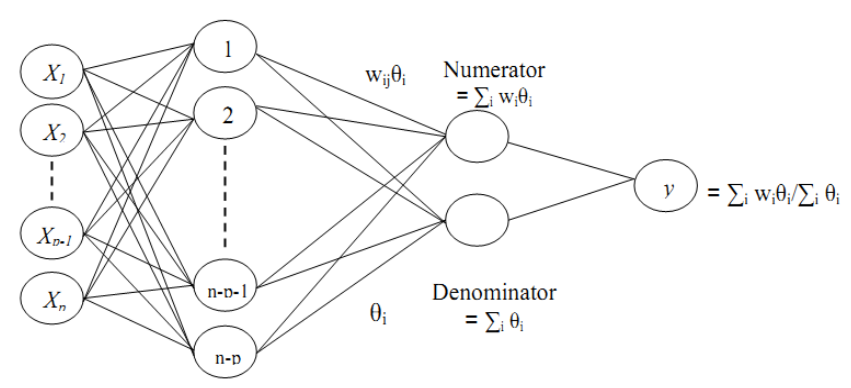

Gambar 2. Arsitektur GRNN

\subsection{Validasi}

Validasi dilakukan sebagai proses pengujian kinerja jaringan untuk masing-masing model terhadap bahan uji, masukannya berupa data uji yang sama namun menggunakan nilai bobot pelatihan yang berbeda. Kinerja jaringan dapat dilihat berdasarkan nilai perbandingan target yang terpenuhi dan jumlah data uji.

\section{Hasil dan Pembahasan}

Program pengolahan citra akan menerjemahkan informasi yang terdapat didalam citra pelatihan dan citra uji. Informasi yang dihasilkan oleh program pengolahan citra berupa data-data numerik yang didapat dari citra daging sapi segar, citra daging sapi segar yang didinginkan, citra daging sapi segar yang dibekukan, citra daging sapi segar dikeringkan, citra daging sapi segar direndam air, citra daging sapi gelonggongan, citra daging sapi busuk, citra daging sapi busuk yang dibekukan, citra daging sapi busuk yang didinginkan dan citra daging sapi busuk dikeringkan. Keluaran dari program pengolahan citra adalah data berupa nilai $\mathrm{R}, \mathrm{G}, \mathrm{B}$, color value, indeks $\mathrm{R}$, indeks $\mathrm{G}$, indeks $\mathrm{B}$, hue, saturation dan intensity.

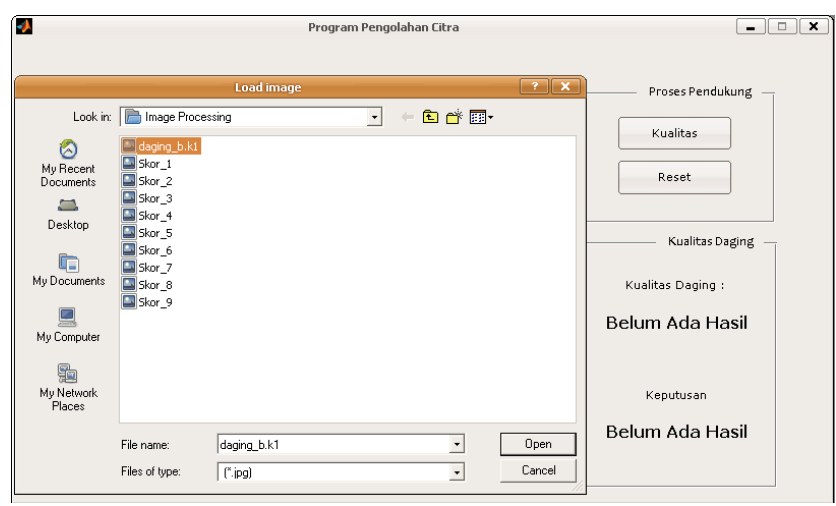

Gambar 3. Tampilan program pengolahan citra saat dijalankan

\subsection{Sifat Jenis Daging sapi berdasarkan pengolahan citra}

Karakteristik RGB untuk daging sapi segar, daging sapi segar yang didinginkan, daging sapi segar yang dibekukan, daging sapi segar dikeringkan, daging sapi segar direndam air, daging sapi gelonggongan, daging sapi busuk, daging sapi busuk yang dibekukan, daging sapi busuk yang didinginkan dan daging sapi busuk dikeringkan. Masing-masing memiliki nilai rata-rata seperti ditunjukkan pada Gambar 4, 5, 6, 7, 8 dan 9. Jika dilihat dari rata-ratanya yang tertinggi adalah dagin sapi segar dingin dan terendah adalah daging busuk kering. Perbedaan ini lebih memudahkan program dalam membedakan jenis daging sapi segar dingin dan daging sapi busuk kering berdasarkan warna merah.

Karakteristik HSI daging sapi segar, daging sapi segar yang didinginkan, daging sapi segar yang dibekukan, daging sapi segar dikeringkan, daging sapi segar direndam air, daging sapi gelonggongan, daging sapi busuk, daging sapi busuk yang dibekukan, daging sapi busuk yang didinginkan dan daging sapi busuk dikeringkan. Rata-rata sebaran nilai $\mathrm{H}$ (Hue) untuk masing-masing jenis daging dapat dilihat pada Gambar 10, dari data tersebut terlihat bahwa rata-rata tertinggi terdapat pada jenis daging sapi busuk kering dan terendah terjadi pada jenis daging busuk dingin, sehingga perbedaan nilai hue ini akan memudahkan dalam proses pembelajaran dan validasi dalam membedakan kedua jenis daging tersebut.

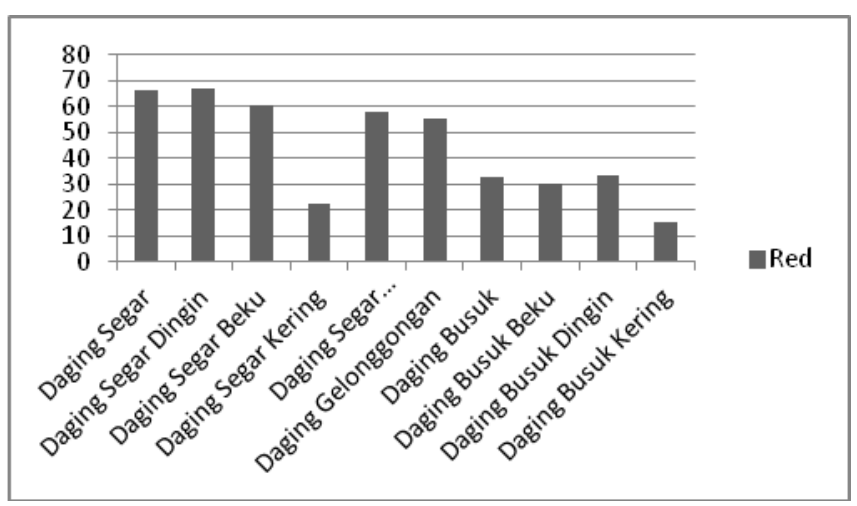

Gambar 4. Sebaran nilai warna merah (R) pada setiap jenis daging 


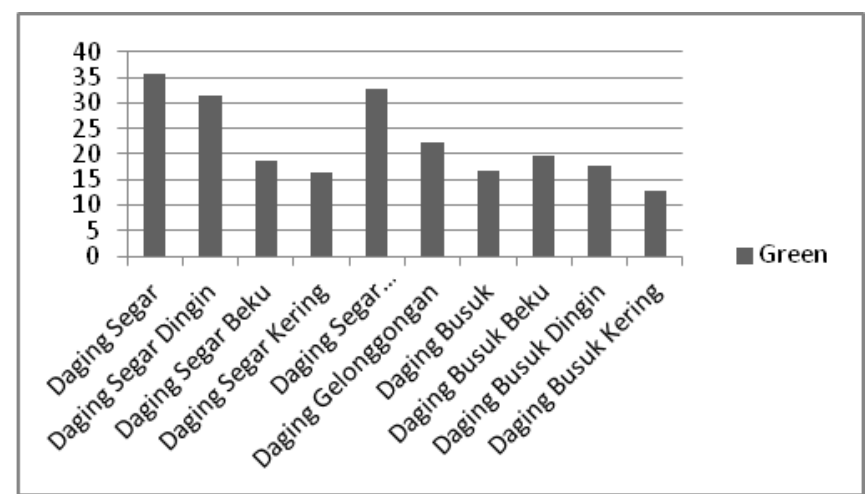

Gambar 5. Sebaran nilai warna hijau (G) pada setiap jenis daging

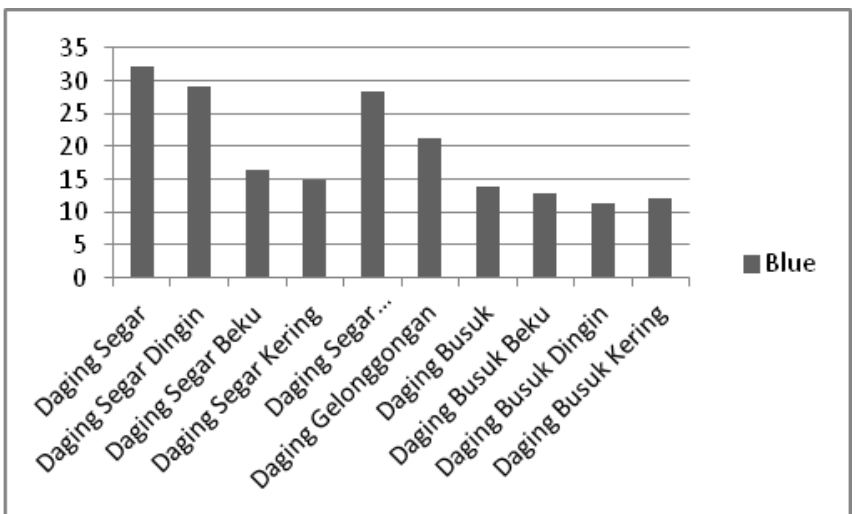

Gambar 6. Sebaran nilai warna biru (B) pada setiap jenis daging

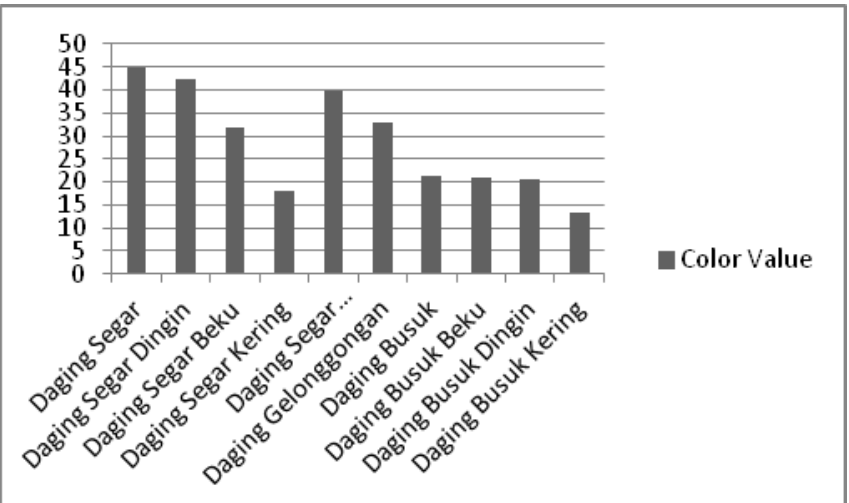

Gambar 7. Sebaran nilai color value (CV) pada setiap jenis daging

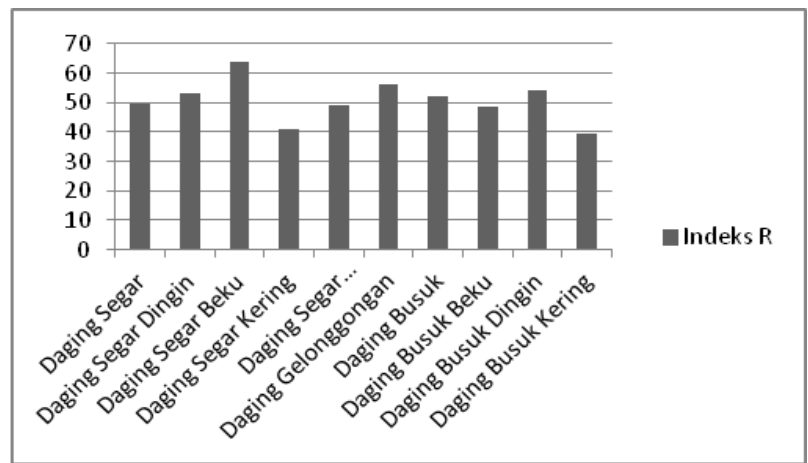

Gambar 8. Sebaran nilai indeks warna merah pada setiap jenis daging

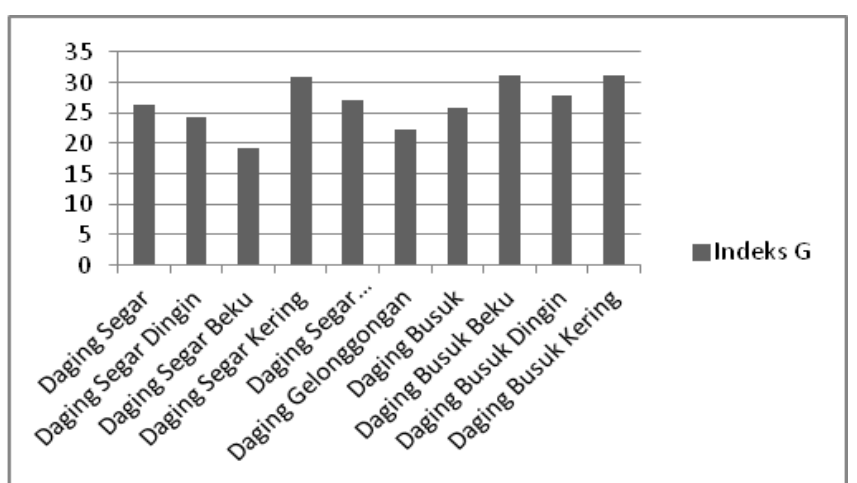

Gambar 9. Sebaran nilai indeks warna hijau pada setiap jenis daging

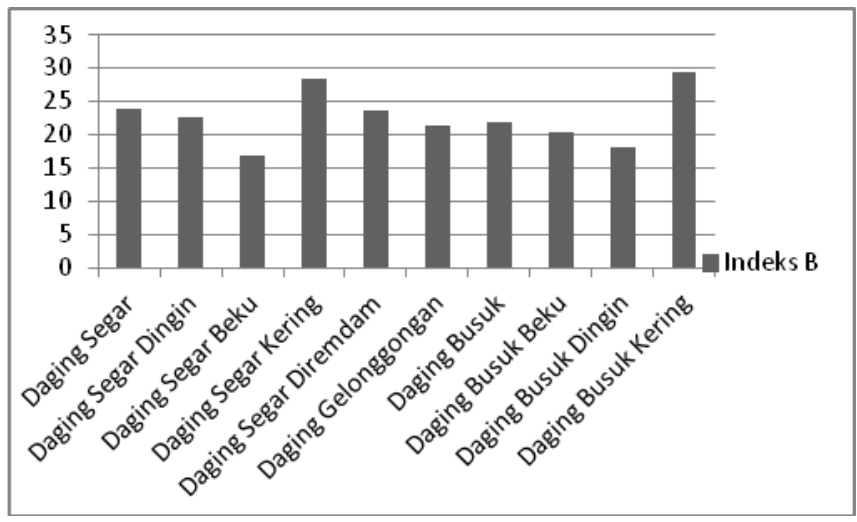

Gambar 10. Sebaran nilai indeks warna biru pada setiap jenis daging

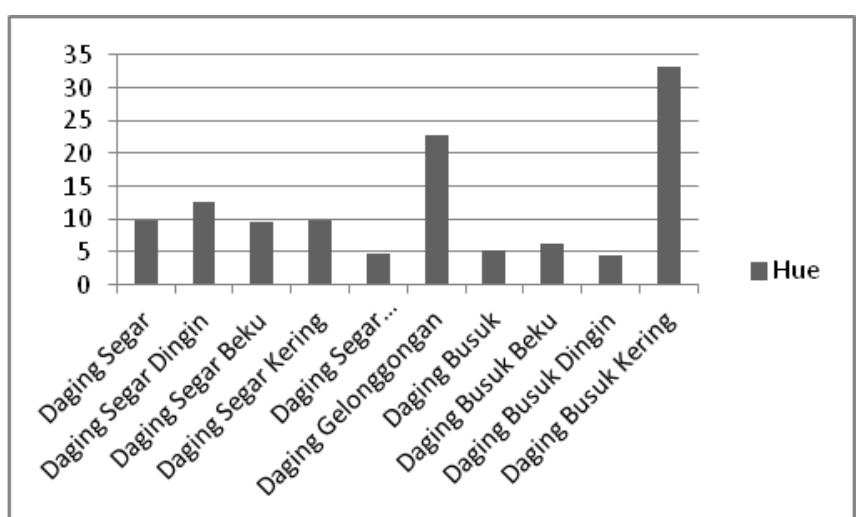

Gambar 11. Sebaran nilai hue $(\mathrm{H})$ pada setiap jenis daging

Sebaran nilai S (Saturation), rata-ratanya untuk setiap jenis daging dapat dilihat pada Gambar 12, dimana nilai tertinggi didominasi oleh daging sapi segar beku dan terendah terjadi pada jenis daging busuk kering. Perbedaan ini lebih memudahkan program dalam membedakan jenis daging sapi segar beku dan daging sapi busuk kering berdasarkan nilai saturasi.

Sebaran warna I (Intensity), rata-ratanya untuk setiap jenis daging dapat dilihat pada Gambar 13. Nilai tertinggi terdapat pada jenis daging sapi segar dan terendah pada jenis daging saoi busuk kekring, sehingga dimungkinkan bahwa kedua jenis biji ini lebih mudah dibedakan berdasarkan intenitasnya. 


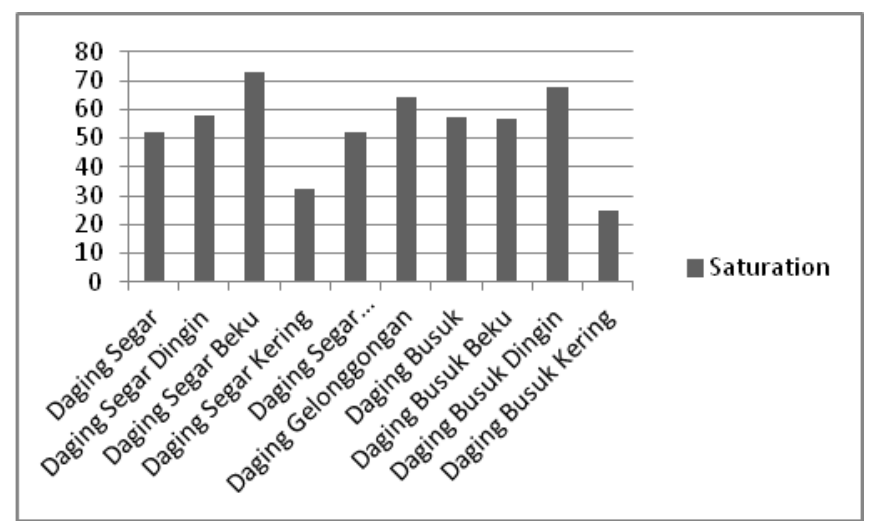

Gambar 12. Sebaran nilai saturation (S) pada setiap jenis daging

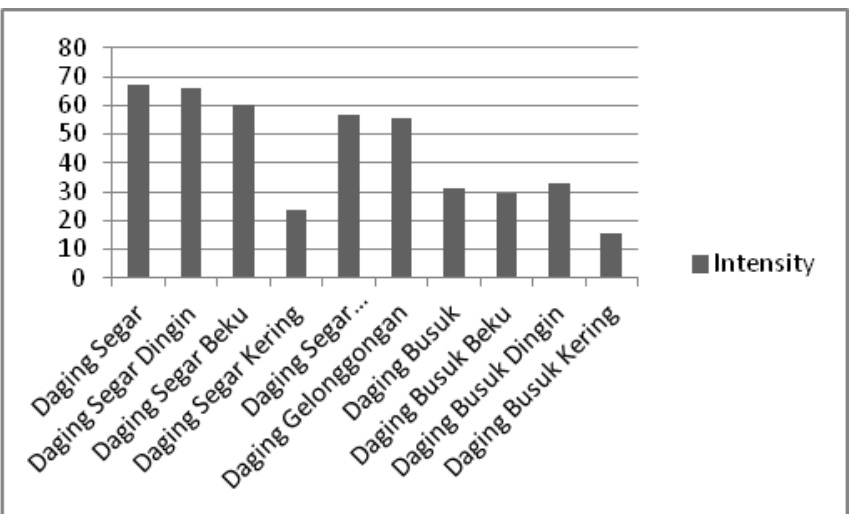

Gambar 13. Sebaran nilai intetnsitu (I) pada setiap jenis daging

\subsection{Pelatihan}

Hasil pelatihan adalah nilai bobot yang disimpan pada file dengan ekstensi MAT yang digunakan oleh program validasi untuk mengidentifikasi jenis daging. Pada proses pelatihan backpopagation konstanta laju pembelajaran ( $\eta$ ) sebesar 0.7 , konstanta momentum $(\alpha)$ sebesar 0.8 dan nilai persamaan sigmoid $(\sigma) 1$.

\subsection{Validasi}

Validasi dilakukan pada semua jenis daging dengan jumlah data uji seluruhnya 102 yang terdiri dari 13 daging sapi segar, 10 daging sapi segar yang didinginkan, 11 daging sapi segar yang dibekukan, 12 daging sapi segar dikeringkan, 11 daging sapi segar direndam dengan air, 9 daging sapi gelonggongan, 8 daging sapi busuk, 8 daging sapi busuk yang dibekukan, 13 daging sapi busuk yang didinginkan dan 7 daging sapi busuk dikeringkan.

Selain menggunakan data uji yang berjumlah 102 validasi juga memerlukan masukan lain berupa nilai bobot yang telah dihasilkan oleh masing-masing model, baik model backpropagation maupun moel GRNN.

Hasil identifikasi untuk jenis data uji semua jenis daging menggunakan model jaringan saraf tiruan backpropagation disajikan pada tabel 4.1. Ketepatan indentifikasi yang memuaskan terjadi pada jenis daging dengan akurasi $100 \%$ hanya terjadi pada daging sapi busuk, diduga disebabkan tidak berbedanya nilai input Green, dan indeks G.
Akurasi yang menunjukan nilai diatas $50 \%$ terjadi pada jenis daging segar direndam dengan akurasi 54,5\% dengan rincian 6 daging segar direndam, 3 daging sapi segar beku, 1 daging sapi segar kering dan 1 daging sapi gelonggongan. Munculnya daging sapi segar beku diduga disebabkan samanya nilai input color value dan nilai input intensitas. Munculnya daging sapi segar kering diduga disebebkan tidak bebedanya nilai input indeks $G$, sedangkan munculnya daging sapi gelonggongan diduga disebabkan kesamaan nilai input green, blue, dan color value. Sedangkan ketelitian identifikasi jenis daging dengan akurasi dibawah $50 \%$ terjadi pada jenis daging sapi segar, daging sapi segar beku, daging sapi segar dingin, daging sapi segar kering, daging sapi busuk beku, daging sapi busuk dingin dan daging sapi busuk kering. Berbeda dengan jenis daging lainnya, jenis daging sapi gelonggongan memiliki tingkat ketelitian yang sangat rendah dengan nilai akurasi $0 \%$ diduga ini disebabkan oleh nilai parameter input Green dan indeks G yang sama.

Daging segar memiliki ciri warna merah lembut, validasinya hanya sebesar $23 \%$ dengan rincian 3 diidentifikasi sebagai daging sapi segar, 4 sebagai daging sapi segar beku, 5 sebagai daging sapi segar dingin dan 1 sebagai daging sapi segar kering. Munculnya daging sapi segar beku, diduga disebabkan tidak berbedanya nilai input red dan hue, munculnya daging sapi segar dingin diduga disebabkan tidak berbedanya nilai input hue, dan munculnya daging sapi segar kering diduga disebabkan oleh tidak berbedanya nilai input indeks $\mathrm{G}$.

Daging sapi segar dingin memiliki ciri warna merah terang, validasinya menunjukkan nilai akurasi sebesar $40 \%$ dengan rincian 4 teridentifikasi sebagai daging sapi segar dingin, 3 sebagai daging sapi segar beku dan 3 sebagai daging sapi segar dingin. munculnya daging sapi segar beku diduga disebabkan tidak berbedanya nilai input intensitas, sedangkan munculnya daging sapi segar kering diduga disebabkan oleh kesamaan sifat data yang hampir sama pada setiap nilai input.

Daging sapi segar beku memiliki ciri warna merah pudar, validasinya menunjukkan nilai akurasi sebesar $36,3 \%$ dengan rincian 4 teridentifikasi sebagai daging sapi segar beku, 3 sebagai daging sapi segar dingin dan 3 sebagai daging sapi segar kering. munculnya daging sapi segar dingin diduga disebabkan tidak berbedanya nilai input intensitas, sedangkan munculnya daging sapi segar kering diduga disebabkan tidak berbedanya nilai input blue.

Daging sapi segar kering memiliki ciri warna hitam keabu-abuan, validasinya menunjukkan nilai akurasi sebesar $8,3 \%$ dengan rincian 1 teridentifikasi sebagai daging sapi segar kering, 2 sebagai daging sapi segar rendam, 5 sebagai daging sapi gelonggongan dan 4 sebagai daging sapi busuk. Munculnya daging sapi segar rendam diduga disebabkan oleh kesamaan nilai input pada indeks $\mathrm{G}$ dan indeks $\mathrm{B}$, sedangkan munculnya daging sapi busuk diduga memiliki kesamaan nilai input green, blue, dan color value.

Daging sapi busuk beku memiliki warna hitam kemerahan, validasinya hanya memberikan nilai akurasi 37,5\% dengan rincian 3 daging sapi busuk, 3 daging sapi busuk beku dan 2 daging sapi busuk dingin. munculnya daging sapi busuk beku diduga disebabkan tidak 
berbedanya nilai input blue dan color value, sedangkan munculnya daging sapi busuk dingin diduga disebabkan oleh kesamaan nilai input color value dan nilai input intensitas.

Daging sapi busuk dingin memiliki ciri warna merah kehijauan, validasinya memberikan nilai akurasi 38,4\% dengan rincian 5 daging sapi busuk dingin, 1 daging sapi busuk dan 7 daging sapi busuk beku. Munculnya daging sapi busuk diduga disebabkan oleh kesamaan nilai input blue dan nilai input indeks green.

Daging sapi busuk kering memiliki ciri warna khas, namun hanya memberikan nilai akurasi sebesar 28\% dengan rincian 2 daging sapi busuk kering, 2 daging sapi busuk beku, 2 daging sapi busuk dingin dan 1 tidak teridentifikasi. Munculnya daging sapi busuk beku diduga disebabkan oleh samanya nilai input indeks $G$ dan munculnya daging sapi busuk dingin diduga disebabkan oleh tidak berbedanya nilai input green, sampel uji yang tidak teridentifikasinya diduga disebabkan oleh nilai input intensitas yang kecil.

Untuk hasil identifikasi semua data uji pada semua jenis daging menggunakan model jaringan saraf tiruan General Regression Neural Network. Ketepatan indentifikasi yang memuaskan dengan akurasi $100 \%$ hanya terjadi pada daging sapi busuk dingin, diduga hal ini terjadi karena daging sapi busuk dingin memiliki nilai input red dan intensitas yang tidak berbeda.

Ketelitian identifikasi jenis daging yang memberikan nilai akurasi diatas $50 \%$ terjadi pada jenis daging sapi segar sebesar 92,3\%, daging sapi segar dingin $81,8 \%$ daging sapi segar beku 90\%, daging sapi segar kering 83,3, daging sapi segar direndam 72,7 daging sapi gelonggongan $55,5 \%$, daging sapi busuk beku 87,5 dan daging sapi busuk kering $57,1 \%$. Sedangkan nilai akurasi yang berada dibawah $50 \%$ hanya terjadi pada satu jenis daging yaitu daging sapi busuk yang memberikan nilai akurasi sebesar $37,5 \%$.

Daging segar memberikan nilai akurasi yang cukup memuaskan hingga 92\%, dengan rincian 12 sebagai daging sapi segar dan 1 tidak teridentifikasi, tidak teridentifikasinya sampel uji diduga disebabkan oleh terlalu besarnya nilai parameter blue Ketelitian identifikasi pada jenis daging sapi segar beku memberikan nilai akurasi sebesar 90\% dengan rincian 9 teridentifikasi sebagai daging sapi segar beku dan 1 sebagai daging sapi segar dingin. Munculnya daging sapi segar dingin diduga disebabkan oleh tidak berbedanya nilai input pada intensitas.

Daging sapi segar dingin memberikan tingkat akurasi sebesar $81,8 \%$ dengan rincian 9 daging sapi segar dingin dan 2 daging sapi gelonggongan. Munculnya daging sapi gelonggongan diduga adanya kesamaan nilai red dan intensitas.

Pada jenis daging sapi segar kering memberikan nilai akurasi 83,3\% dengan rincian 10 sebagai daging sapi segar kering, 1 daging sapi busuk kering dan 1 tidak teridentifikasi. Munculnya daging sapi busuk kering diduga disebabkan oleh kesamaan nilai input antara indeks $\mathrm{R}$, dengan indeks $\mathrm{B}$, dan saturation dengan intensitas, sedangkan tidak teridentifikasinya sampel uji diduga disebabkan oleh rendahnya nilai input indeks B.
Daging sapi segar direndam validasinya memiliki nilai akurasi sebesar 72,2\% dengan rincian 8 daging sapi segar direndam, 1 daging sapi segar dingin, 1 daging sapi gelonggongan dan 1 tidak teridentifikasi. Munculnya daging sapi segar dingin diduga disebabkan oleh rendahnya nilai input indekB dan hue dan munculnya daging sapi gelonggongan diduga adanya kesamaan nilai red dan intensitas.

Daging sapi gelonggongan memiliki nilai akurasi sebesar 55,5\% dengan rincian 5 teridentifikasi sebagai daging sapi gelonggongan 2 sebagai daging sapi segar dingin 1 sebagai daging sapi segar dan 1 tidak teridentifikasi. Munculnya daging sapi segar dingin diduga disebabkan oleh adanya kesamaan nilai input green dan indekG, munculnya daging sapi segar diduga disebabkan oleh tingginya nilai intensitas. Sedangkan tidak teridentifikasi diduga disebabkan oleh kesamaan nilai input indeks $\mathrm{R}$ dan intensitas.

Daging sapi busuk memberikan nilai akurasi sebesar $37,5 \%$ dengan rincian 3 sebagai daging sapi busuk, 2 busuk sapi gelonggongan, 2 busuk sapi beku dan 1 busuk dingin. Munculnya daging sapi gelonggongan diduga disebabkan oleh kesamaan nilai input red dan intensitas, mulculnya daging sapi busuk beku diduga disebabkan oleh tidak berbedanya nilai input red, indekB dan intensitas, sedangkan munculnya daging sapi busuk dingin diduga disebabkan oleh tidak berbedanya nilai input antara red dengan intensitas dan green dan blue.

Daging busuk validasinya memberikan nilai akurasi $87,5 \%$ dengan rincian 7 daging busuk, 1 daging busuk beku, munculnya daging busuk beku diduga disebabkan tidak berbedanya nilai input green dengan color value.

Daging sapi busuk kering validasinya memberikan nilai akurasi sebesar $57,1 \%$ dengan rincian 4 daging sapi busuk kering, 2 daging sapi segar kering dan 1 tidak teridentifikasi. Munculnya daging segar kering diduga disebabkan adanya kesamaan nilai input red dan saturation, sedangkan tidak teridentifikasi jenis daging diduga disebabkan oleh rendahnya nilai input intensitas.

Perbandingan akurasi hasil identifikasi antara jaringan backproagation dan general regression neural network dapat dilihat pada tabel 4.3. Hasil identifikasi menunjukan nilai akurasi yang berbeda pada setiap jenis daging.

\subsection{Perbandingan}

Setelah mendapatkan nilai akurasi dari masing-masing model, baik nilai akurasi yang didapatkan dari model jaringan backpropagation maupun nilai akurasi yang didapatkan dari model jaringan GRNN. Dengan nilai tersebut kita dapat melakukan perbandingan, model manakah yang memiliki nilai akurasi ketepatan yang lebih baik (Tabel 3).

Pada tabel diatas terdapat hasil akurasi identifikasi backpropagation $0 \%$ yaitu pada daging sapi gelonggongan, meskipun data uji yang digunakan memiliki kemiripan dengan data training. Nilai akurasi $0 \%$ ini menunjukan bahwa tidak satupun data uji dikenali sebagai daging sapi gelonggongan. Hasil validasi ini sangat dipengeruhi oleh bobot yang dihasilkan pada saat pelatihan. 
Tabel 3. Perbandingan nilai akurasi backpropagation dan GRNN

\begin{tabular}{lcc}
\hline \multirow{2}{*}{ Jenis Daging } & \multicolumn{2}{c}{ Akurasi (\%) } \\
\cline { 2 - 3 } \multicolumn{1}{c}{ Sapi } & Backpropagation & GRNN \\
\hline Segar & 23 & 92,3 \\
Segar Beku & 36,3 & 90 \\
Segar Dingin & 40 & 81,8 \\
Segar Kering & 8,3 & 83,3 \\
Segar Rendam & 54,5 & 72,7 \\
Gelonggongan & 0 & 55,5 \\
Busuk & 100 & 37,5 \\
Busuk Beku & 37,5 & 87,5 \\
Busuk Dingin & 38,4 & 100 \\
Busuk Kering & 28,5 & 57,1 \\
Rata-rata & 29,4 & 81,3 \\
\hline
\end{tabular}

\section{Kesimpulan}

1. Akurasi tertinggi yang dihasilkan oleh jaringan backpropagation adalah $100 \%$ pada jenis daging sapi busuk, sedangkan akurasi terendah adalah $0 \%$ terjadi pada daging sapi gelonggongan. Akurasi tertinggi yang dihasilkan menggunakan jaringan GRNN adalah $100 \%$ pada jenis daging busuk sapi dingin sedangkan jaringan terendah adalah $37,5 \%$ terjadi pada jenis daging sapi busuk.

2. Akurasi rata-rata yang dihasilkan oleh jaringan backpropagation sebesar 29,4\%, sedangkan akurasi rata-rata yang dihasilkan oleh jaringan GRNN adalah $81,3 \%$

3. Secara umum arsitektur jaringan GRNN mempunyai nilai akurasi yang lebih baik.

\section{Daftar Pustaka}

Ahmad, U. 2005. Pengolahan Citra Digital \& Teknik Pemrogramanya. Yogyakarta: Graha Ilmu.
Anonim. 2008. Standar Nasional Indonesia Nomor 3932:2008 Tentang Mutu Karkas dan Daging Sapi. Jakarta: Badan Standar Nasional.

Anonim. 2008. Standar Nasional Indonesia Nomor 3947:1995 Tentang Daging Sapi dan Kerbau. Jakarta: Badan Standar Nasional.

Buckle, K.A., Ronald, A., Edwards, Graham, H.F., Michael, W., 1985. Ilmu Pangan (Terjemahan Hari Purnomo dan Adiono). Jakarta: Direktorat Jenderal Pendidikan Tinggi.

Hariyanto, D., 2009. Studi penentuan nilai resistor menggunakan seleksi warna model hsi pada citra 2D. Jurnal Telkomnika, Volume 1, Nomor 1. Universitas Ahmad Dahlan, Yogyakarta.

Kastamana, R., Abdulfatah, F.W., 2009. Analisis Kinerja Perangkat Lunak Pengolah Citra dengan Menggunakan Beberapa Metode Klasifikasi untuk Menentukan Kualitas Buah Manggis. Proceeding of Kebijakan dan Aplikasi Teknologi Informasi dan Komunikasi untuk Peningkatan Daya Saing Agribisnis Indonesia, Institut Pertanian Bogor.

Kusumadewi, S., 2003. Artifical Intellegence (Teknik dan Aplikasinya). Penerbit Graha Ilmu, Yogyakarta.

Murni, A., 1993 Pengantar Pengolahan Citra. Elex Media Komputindo, Jakarta dan Pusat Antar Universitas Ilmu Komputer Universitas Indonesia.

Putra, D., 2010. Pengolahan Citra. Penerbit Andi, Yogyakarta.

Raharjo, S., 2010. Aplikasi madu sebagi pengawet daging sapi giling segar selama proses penyimpanan. Skripsi, Universitas Sebelas Maret, Surakarta.

Siang, J..J., 2005. Jaringan Syaraf Tiruan \& Pemrogramannya Menggunakan Matlab. Penerbit Andi, Yogytakarta.

Sofi'i', I., Astika, W., Suroso, 2005. Penentuan jenis cacat biji kopi dengan pengolahan citra dan artificial neural network. Jurnal Keteknikan Pertanian, Volume 19, Nomor 2, IPB Bogor.

Somantri, A.S., Miskiyah, Broto, W., 2009. Identifikasi mutu fisik jagung dengan menggunakan pengolahan citra dan jaringan syaraf tiruan. Jurnal Standarisasi, Volume 10, Nomor 3, Badan Standar Nasional, Jakarta.

Somantri, A.S., Miskiyah, Broto, W., 2009. Pendugaan tingkat keamanan jagung dengan menggunakan pengolahan citra digital dan jaringan syaraf tiruan. Jurnal Standarisasi, Volume 11, Nomor 1, Badan Standar Nasional, Jakarta.

Sutrisno, Edris, Ismi, M., Sugiyono, 2009. Aplikasi jaringan syaraf tiruan untuk pendugaan mutu pemeraman pisang raja bulu setelah penyimpanan. Proceeding of Seminar Nasional Himpunan Informatika Pertanian Indonesia, Institut Pertanian Bogor.

Suyantohadi, A., Hariadi, M., Purnomo, M.H., 2008. Artificial Life Model Pertumbuhan Tanaman Kedelai Menggunakan Metoda Neural Network dan Lindenmayer System. Institut Teknologi Sepuluh November, Surabaya. 